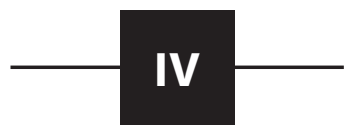

\title{
DEBATE: REFLECTIONS ON COVID-19
}

\section{COVID-19, Religious Markets, and the Black Church}

\author{
Marla Frederick
}

My Facebook timeline lit up in early April. The picture kept appearing in post after post from close friends and respected colleagues. Regardless of whose timeline it came from, the message was the same. As of 3 April, seven leaders of the Church of God in Christ, bishops and superintendents of the Michigan district, had died of COVID-19. A photograph captioned "The Historic First Jurisdiction of Michigan Mourns the Loss of So Great a Cloud of Witnesses" showed the seven men who had all recently died-Supt. Leon R. McPherson, Sr., Supt. Myron E. Left, Bishop Robert L. Harris, Bishop Robert E. Smith, Sr., Supt. Kevelin B. Jones, Sr. Supt. Paul E. Hester, Sr., and Supt. John D. Beverly. By 20 April, the report had grown more ominous. A story posted in Charisma News led with a simple title "Up to 30 COGIC Bishops, Leaders Die from COVID-19" (Spaudo 2020). Death hovered over the church. A tragedy of epic proportions was unfolding in one of the most storied black religious institutions in the country, the nation's first incorporated Pentecostal denomination. ${ }^{1}$

The great tragedy of the COGIC leaders' sickness and ultimate death during this global pandemic is that they have been traced to annual religious convocations that the leaders attended in March 2020. The services were conducted before there was universal consensus from the government or other agencies that gatherings such as church services present dangerous hotspots for the virus to spread. The national debate over church services devolved almost immediately into a political battle over religious freedom, making the possibility of ordering churches closed even more complicated. Nevertheless, the passing of leaders like those in the Church of God in Christ, along with the death of pastors, choir members, and worshipers from other religious communities, brought into sharp relief the need for immediate change in how religious communities should gather during COVID-19. ${ }^{2}$ Many of them subsequently canceled in-person events and went completely online.

The transition to virtual service as a result of COVID-19 has disrupted the ways in which religious communities think about worship service and has required them to rethink several traditions, among them (1) how practitioners experience religious community, (2) how they understand the business models that drive online and in-person service, and (3) how they might communicate most effectively with a simultaneously smaller church audience, but a possibly wider Internet audience. These changes are taking place alongside a rejuvenated Movement for Black Lives, which has disrupted normative social claims to individual responsibility as the harbinger of social outcomes and has highlighted instead the role of social systems in determining such outcomes. These developments disrupt evangelical and prosperity theologies that foreground individual sins 
and individual blessings and cast new light on the possibilities of liberationist theologies for interpreting the Gospel. Given the ways in which evangelical and prosperity gospels have benefited from religious television broadcasting, the turn to online religion may not only provide a new means of disseminating religious messages; it may also alter altogether the types of religious messages that gain traction, democratizing the very means and message of the Gospel.

\section{Broadcasting Religion}

When I wrote Colored Television: American Religion Gone Global (2015), I argued that American religious broadcasting - with its emphasis on individualism, capital accumulation, and spiritual blessing-was no longer primarily the purview of white evangelical and charismatic preachers like Billy Graham, Oral Roberts, Kenneth Hagin, and Kenneth Copeland. Instead, black ministers and white female televangelists had just as readily adopted the theological tenets and at times more effectively spread the message to people across the globe-in the US, Europe, Africa, Latin America, and the Caribbean. With an ethnographic focus on Jamaica, I suggested that the social conditions created by ineffective government rendered people in some areas more vulnerable to poverty and sexual exploitation. Televangelists offered hope through promises of God's supernatural power to restore finances, sustain family relations, and restore personal wholeness. I focused my analysis on what I determined were the interests of television consumers, producers, and distributors of the message. The interrelated nature of these entities drove the demand and style of religious media. Consumers needed hope and entertainment; producers needed to amplify their messages of possibility in order to generate funds from consumers to pay for the airtime; and distributors, particularly those outside the US, needed an ever-growing supply of producers to fill the demands of 24-hour television. This neoliberal, market-driven model of ministry, which has framed much of the last 40 to 50 years of religious broadcasting, exhaustingly replicated itself.

The immediate immersion into a digital religion platform is set to disrupt much of this model; and the impact on American religion, and African-American religion more specifically, stands to be tremendous. While a number of churches have expanded to live streaming their services over the years, the near complete overhaul of the religious landscape to online platforms because of the COVID-19 pandemic is set to have a long-lasting influence on the church community. One can point to the loss of the rituals of birth (baby dedications) and death (funerals) as immediate casualties of COVID-19, or the massive loss of income from weekly services and thus the strain on church budgets (salaries, outreach efforts, building maintenance). All of these are key areas of concern that will impact churches; many small and rural churches with older congregations will likely struggle to stay afloat and/or keep pace with the changes. The potential loss here is as yet unknown. At the same time, it is important to ask about the possibilities that come with online ministry. Based on my previous research and my observations of various trends in online religion during this COVID moment, it is clear that the landscape is changing, although to what degree and for how long remain to be seen.

\section{Of Religious Practice and Community}

With online religion, the changes in Sunday morning service, Bible study, children's church, funerals, and even musical performances are far-reaching. ${ }^{3}$ The innovation that has marked these changes for some ministries has increased their audiences. In preparing for Sunday morning service, many megachurches that already had television or online ministries are pre-recording 
their services during the week and broadcasting the service with a modified praise team in the background leading the online congregation in worship. Other churches have turned to a model with the pastor preaching from his/her living room, often sitting in front of a fireplace, offering a simple three-point message for the week. Still others have tried to recreate the Sunday morning worship experience with a modified crowd of praise team leaders, key deacons, and the media team as the audience in place for the live service. To broadcast they use various platforms, including Facebook, YouTube and even Zoom with its capacity for participant feedback. In the earliest days of the pandemic, a Saturday Night Live skit satirized the sudden move to online church and the mishaps that attended the move, such as members on Zoom not placing their microphones on mute and talking over the pastor during the sermon. While comedic, the skit drove home the point that this tremendous and sudden shift is still in an experimental phase.

At the same time that ministers are figuring out their form of presentation, church choirs and musicians have had to innovate their musical performance. Many have had to perform a single choral piece while recording from different locations. Ethnomusicologist Braxton Shelley (2020) theorizes this multi-vocal choral work sung by musicians in different locations as 'digital antiphony'.

One church, highlighted at the end of Colored Television for its cutting-edge approach to religious broadcasting, is now a leader in online ministry. Having temporarily left religious television several years ago because of the astronomical costs, the church's members decided to invest in their online presence early. Not only have they taken their entire church service online, but they are in the process of building an online religious television station, HOPE TV. Their weekly online presence includes not only the Sunday morning worship service, but also programming for every day of the week. The lineup for one day included:

8:30 AM "Get Up and Exercise"

9:30 "Morning Dew" Devotional with Dr. E. Dewey Smith

12:30 "Forever Young" discussions for senior citizens in the church

4:30 PM "Marriage Matters" talk show

6:00 PM “Sound Mind: Mental Health Matters" discussion with a board-certified psychologist

Innovations like this speak to the possibilities of online religion and the capacity to maintain religious community, even as the pandemic forces us all to shelter in place. In this way churches help provide contexts for meaningful human connection that stems the tide of isolationism precipitated by quarantine. What it means to experience religious community is expanding and with it the theological and social norms that attend traditional service.

\section{Of Business and Theological Leanings}

At the same time that the form of worship services is changing, so too are some of the messages. The movement to online religious service offers a chance to disrupt religious broadcasting writ large by democratizing the places where leaders can distribute messages. In Colored Television, I discuss the resistance toward liberation theology on religious television stations dominated by white evangelical and charismatic owners (Frederick 2015: 133). But the space of the Internet is not owned nor controlled in the same way. Anyone with a message can post, go live, or launch a podcast, and their success is not dependent upon the hegemonic neoliberal organizations that control paid television broadcasting.

For the African-American church communities, this change is significant. There has long been a variety of churches that fall under the rubric of 'the black church' with a range of approaches to sociality. Reams have been written on the tension within African-American communities between 
the liberationist thrust of the church and the more conservative thrusts. ${ }^{4}$ Scholars have narrated a long tradition of liberative work dating from the labor of the African Methodist Episcopal Zion (AMEZ) Church and the African Methodist Episcopal (AME) Church in the abolitionist movement to the work of black churches in the civil rights movement and ongoing battles for racial justice. With this triumphalist narrative of 'the black church', more conservative churches and ideological positions have been silenced in the literature by the more dominating narrative of liberation. In Watch This! The Ethics and Aesthetics of Black Televangelism, Jonathan Walton (2009) contends that despite the conservatism of much of black religion, the tradition is most often defined as liberal and progressive. While scholarly attention had moved away from more conservative strands of black religiosity, Walton demonstrates that these same voices were yet growing in places like religious television broadcasting. The three figures whom Walton explored, T. D. Jakes, Creflo Dollar, and Eddie Long, had at the time of the publication of his book the largest churches and the largest television audiences of any black preachers in the country. Their sermons fit into the 'felt-need' model of religious messaging that attracted great crowds.

With the expansion of black religious television broadcasting, the hegemonic tendencies toward individualism and market-driven religion seemed to be the overarching zeitgeist of the moment, overshadowing more social justice-oriented ministries that tied poverty and health crises to a history of institutionalized racism and not a lack of individual faith. It is no real irony that Paula White, the head adviser to President Donald Trump's Evangelical Council, came to prominence through the ministry of T. D. Jakes. While they have taken divergent approaches to politics under Trump's administration, Paula White has long called Jakes her "Father in Ministry" and became a household name by speaking at his "Woman Thou Art Loosed" conferences. Their synergy on the messages of prosperity, personal faith, and market-driven religion diverge only under the hyper-racist politics of the commander in chief. However, the neoliberal market, from which they have both benefited, is now meeting an online religious community that challenges some of their very tenets.

As religious communities have come online through Bible studies and Sunday morning messages, they have increasingly taken up questions raised by the more liberationist arm of the black church and more recently by the Movement for Black Lives. The Samuel Dewitt Proctor Conference, which brings together black justice-oriented ministries from around the country, has taken to morning Facebook Live prayer services that broadcast the prayers of black liberation ministers from around the world. Furthermore, ministries that have always been at the margins of the traditional black church because they are led by women or by members of the LGBTQ community are finding space and audiences on digital platforms. During the pandemic and since the protests, Evette Flunder, presiding bishop of the Fellowship of Affirming Ministries, has hosted a weekly discussion series called "Beyond the Gatekeepers," addressing topics that range from racism and classism to sexism and homophobia in the church and nation. At the same time, 'digital hush harbor' ministries led by women like Melva Sampson (2020), who has disrupted traditional theological and social teachings of the church and has articulated her position on the fringes of the traditional black church, have gained even greater traction online. On the heels of COVID-19 and in the midst of a global Movement for Black Lives, these ministries and others like them are pushing forward conversations within churches on matters of justice.

\section{Of Religious Audiences}

The refocused attention on questions of justice has created an opportunity for churches to more directly attend to the concerns facing today's youth, many of whom are disaffected with the 
church. Like other congregations, black churches have witnessed a decline in youth participation, reflected in a decrease in general church participation, an increase in 'religious nones', as well as a movement of young people toward more African-inspired religious traditions and a movement of more evangelical youth into white evangelical or multi-racial churches. Yet online church serves as a way of recapturing the imagination of young people.

Audiences are still interested in the entertainment value of religious broadcasting, but a younger generation is also engaged in the social justice arm of ministry. Furthermore, those who watch are no longer largely consumers, as when watching religious television; rather, they are active participants in online church. The chat rooms in Zoom and the decision of some pastors who preach to then hold online question and answer sessions have changed the way top-down ministry is performed. At one church in Boston, the Sunday morning service and the Wednesday evening Bible study take the form of a Zoom meeting with the pastor preaching or a panel speaking. Then the chat room opens for discussion and/or the microphone is unmuted, and the listeners are asked to respond. The lines between producers and consumers, clergy and laity are blurred, as listeners introduce their own questions and concerns into the service. During one panel discussion between a pastor and several invited panelists, the youngest participant openly questioned the involvement of the church in the Movement for Black Lives and queried whether the church would be involved in the movement for all black lives, including those who are gay, lesbian, bisexual, and transgender. In this way, the parishioners and the pastors are cocreating the learning experience. At the same time, the online space is providing a moment for younger, often more technologically sophisticated people to push for greater engagement of the church on issues that are important to them.

These types of conversations continue as audiences grow wider and more diverse. Since COVID-19, Christians across racial lines have been challenging white evangelicalism and its sustained support of the Trump administration-an ongoing theme for numerous podcasts, FaceTime Live events, and the like. What is interesting is that these discussions are increasingly causing black parishioners to further rethink their involvement in white evangelicalism, wondering if it is more a political than a spiritual movement, as some religious conservatives have made mask-wearing a matter of religious freedom and their support for Trump a calling from God. Stories have emerged of black pastors and parishioners departing white evangelical spaces, pre-COVID and increasingly post-COVID and Black Lives Matter protests. Some are returning to black church traditions. One story in the New York Times suggested that there has been a 'quiet exodus' (Robertson 2018) of black worshipers from white evangelical churches, given the silence of such churches on matters of racial justice and the ongoing support of Trump by leaders and congregants. ${ }^{5}$

Black churches are further expanding their audiences by at times connecting with online 'influencers' who promote pastors on their platforms, placing churches in front of a broader audience. In one comedic presentation, a social media influencer, Kevin Fredericks (known as KevOnStage), spliced up a pastors' message to his congregation informing them that the church would remain closed during the pandemic and offering them his strict standards for reopening. The comedian interjects his own brand of comedy into the pastor's message, highlighting the pastor's clear instructions that they will return to church "when the NBA reopens ... when the governors' mansions open for tours again ... when the White House opens again for visitation." Until then, "the CHURCH is still open; the building is closed." The attention that Fredericks garnered with his mix of humor brought to light not only the ways in which COVID-19 is affecting black communities, but also the ways in which black religious leaders are innovating their worship services, expanding their viewing audiences through random 'influencer' moments and protecting their communities amid an invisible killer that respects neither 'sinner' nor 'saint'. 
What will happen to the church in the months and years ahead? As anthropologists, we are social scientists, not prophets. Nevertheless, my years of studying the black church and the world of evangelical religious broadcasting suggest that a change is afoot that will have an irrevocable influence on the church. Unlike the proclamations that declared the end of the church with the development of the phonograph, or the decline of the in-person church with the rise of televangelism, it is premature to declare the end of the church tradition because of COVID-19 and the dramatic rise of online religion. This disruption may have been the very thing needed to ensure the longevity of religious practice in a world where many had already ceased attending in-person services. While markets change along with the means and methods of distribution, we must remember that religionists are not just consumers and religious lives cannot simply be reduced to market choices. There is something ethereal that beckons people to houses of worship, whether in the flesh or in the digital universe.

MARLA FREDERICK is the Asa Griggs Candler Professor of Religion and Culture at Emory University's Candler School of Theology and President of the American Academy of Religion. Her research interests include the study of African-American religion, religion and media, and the sustainability of black institutions in a 'post-racial' world. E-mail: marla.frederick@emory.edu

\section{NOTES}

1. The Church of God in Christ (COGIC) is the largest black Pentecostal denomination in the country. Formed in the late 1800s through the leadership of Charles Mason, the church emerged as a critique of Baptist and Methodist denominations whom they believed rejected the call to holiness. It grew to incorporate teachings on the supernatural power of the Holy Spirit after Mason attended what came to be known as the Azusa Street Revival in 1906 in Los Angeles. The revival, led by William Seymour, a black itinerate preacher, emphasized the importance of speaking in tongues as a manifestation of the Holy Spirit. A multi-racial event, the revival was pivotal to the spread of global Pentecostalism as we know it today. COGIC reorganized after the revival, placing an emphasis on the supernatural gifts of God, and became the first incorporated Pentecostal denomination in the US.

2. Several other stories have emerged about the tragic deaths of religious leaders since the pandemic began: a pastor and his wife died within hours of one another in Morrero, Louisiana (Desselle 2020); two people died and 52 others became ill after attending a choir rehearsal in Mount Vernon, Washington (Waldstein 2020); and just outside Detroit, 13 Catholic sisters died from COVID-19 (Waller and Hauser 2020).

3. Scholars like Heidi Campbell (2013) have spent much time contemplating the meaning and social impact of digital religion.

4. For examples of these debates, see Peter Paris's (1985) The Social Teaching of the Black Churches; C. Eric Lincoln and Lawrence Mamiya's (1990) The Black Church in the African American Experience; and Hans Baer and Merrill Singer's (2002) African American Religion: Varieties of Protest and Accommodation.

5. After the pandemic and the racial reckoning of the summer of 2020, a story ran about an important up-and-coming black pastor whose church left the Southern Baptist convention after the death of George Floyd and the protests that ensued (Mwama 2020).

6. KevOnStage's YouTube clip can be viewed at https://www.youtube.com/watch?v=pnLW7Q1--Vo. The clip has received over 235,000 views. 


\section{REFERENCES}

Baer, Hans A., and Merrill Singer. 2002. African American Religion: Varieties of Protest and Accommodation. 2nd ed. Knoxville: University of Tennessee Press.

Campbell, Heidi A., ed. 2013. Digital Religion: Understanding Religious Practice in New Media Worlds. New York: Routledge.

Desselle, Sherman. 2020. "77-Year-Old Westbank Pastor, Wife Both Die after Testing Positive to COVID-19, Family Says." WDSU News, 11 April. https://www.wdsu.com/article/77-year-old-westbank-pastor-wife-both-die-after-testing-positive-to-covid-19-family-says/32113141\#.

Frederick, Marla F. 2016. Colored Television: American Religion Gone Global. Stanford, CA: Stanford University Press.

Lincoln, C. Eric, and Lawrence H. Mamiya. 1990. The Black Church in the African American Experience. Durham, NC: Duke University Press.

Mwaura, Maina. 2020. "Atlanta Church Splits with SBC for Downplaying Racial Issues." Religious News Service, 16 July. https://www.christianitytoday.com/news/2020/july/john-onwuchekwa-leave-sbcafrican-american-atlanta-church.html.

Paris, Peter J. 1985. The Social Teaching of the Black Churches. Philadelphia, PA: Fortress Press.

Robertson, Campbell. 2018. "A Quiet Exodus: Why Black Worshipers Are Leaving White Evangelical Churches.” New York Times, 9 March. https://www.nytimes.com/2018/03/09/us/blacks-evangelicalchurches.html.

Sampson, Melva L. 2020. "Digital Hush Harbors: Black Preaching Women and Black Digital Religious Networks." Fire!!! 6 (1): 45-66. Special issue titled "Theorizing the Digital Black Church.”

Shelley, Braxton D. 2020. "Music, Memes, and Digital Antiphony." Radcliffe Institute Lecture, Cambridge, MA, 11 March.

Spaudo, Jenny Rose. 2020. "Up to 30 COGIC Bishops, Leaders Die From COVID-19." Charisma Magazine, 20 April. https://www.charismamag.com/spirit/church-ministry/45147-up-to-30-cogic-bishops-leaders-.

Waldstein, David. 2020. "Coronavirus Ravaged a Choir. But Isolation Helped Contain It." New York Times, 12 May. https://www.nytimes.com/2020/05/12/health/coronavirus-choir.html.

Waller, Allyson, and Christine Hauser. 2020. "Convent in Michigan Loses 13 Sisters to Covid-19." New York Times, 23 July. https://www.nytimes.com/2020/07/23/us/nuns-die-covid-michigan.html.

Walton, Jonathan L. 2009. Watch This! The Ethics and Aesthetics of Black Televangelism. New York: New York University Press. 


\title{
$\longrightarrow$ \\ Can You See the Big Picture? \\ COVID-19 and Telescoping Truth
}

\author{
Yunus Doğan Telliel
}

On a number of recent occasions, I have found myself in conversation with various Turkish acquaintances on the 'meaning' of the coronavirus. I have been told and encouraged to believe that such a destructive disease could only have come into existence via the calculated machinations of China, the US, the Rothschild family, Bill Gates, or other powerful global figures. ${ }^{1}$ Almost invariably, my uncertainty toward these narratives is simultaneously diagnosed and derided: "You are not looking at the big picture!"

The metaphor of 'the big picture' rose to prominence in Turkish public life in 2013. In response to the Gezi Park protests, then Turkish Prime Minister (and current President) Recep Tayyip Erdoğan scolded protestors for refusing to "see the big picture" and "understand the games that are being played on them” (Anadolu Agency 2013). In Erdoğan's eyes, the three months of civil unrest had not arisen from genuine opposition to urban development projects in Istanbul, but had been deliberately orchestrated by powerful outside forces intent on destabilizing Turkey. If the protestors could only see the big picture, they would realize they had been manipulated into serving the hidden agendas of, for example, European elites, George Soros and the Open Society Foundations, or international human rights organizations (cf. Altun and Erensü 2014; Nefes 2017). Indeed, 2013 marked a rapid turn toward anti-globalism and local and national (yerli ve milli in Turkish) policies in the government party, as well as an end to the flirtation with liberal Islam. 'The big picture' has since become an essential keyword in pro-government pundits' discourse. Likewise, as the Turkish public continues to grapple with numerous uncertainties and threats posed by the ongoing pandemic, it now appears regularly in conversations about COVID-19 on television news shows, social media, and even WhatsApp group chats among friends and family.

'Seeing the big picture' is surely a cliché, but it is also one of those metaphors that registers as either truth or farce: it leaves no room for irony. Unsurprisingly, big picture talk often traffics in misinformation and hosts a number of conspiracy theories. It is especially popular among those who believe that COVID-19 was deliberately misrepresented by the World Health Organization, Bill Gates, or telecommunication companies. Here, big picture talk points ultimately to globalist (küreselci) plans to undermine the nation-state as well as to remove Erdoğan, Trump, and other political leaders who are deemed as defenders of 'national interest' in their countries. Big picture talk also signals a way of thinking about the truth. Perhaps more accurately, as a spatial and scalar metaphor, the big picture is primarily a way of looking for or at the truth. It relies on cultural affinities between sight and evidence (cf. Bloch 2008), yet it shuns one kind of sight and privileges another. In this article, I am interested in this double movement: What kind of truth claims emerge or are effaced in big picture talk? How does a concern for truth translate into anti-globalist politics? The first half of the article focuses on the rhetorical power of 'the big 
picture' in the Turkish context and discusses what I call 'telescoping truth', which constructs a particular relationship between anti-globalism and the truth. In the second half, I discuss how telescoping truth animates a politico-theological critique of liberal globalism.

The big picture is taken from the strategist's vocabulary. Indeed, 'looking at the big picture' is a catchphrase used by the American geopolitical intelligence company Stratfor (allegedly a partner of American 'deep state', according to some Turkish pundits). ${ }^{2}$ Since the Gezi Park protests in 2013, the government party representatives and pro-government intellectuals have invoked the big picture as a way of fending off criticisms of the Turkish state's actions or inactions in numerous arenas (from military operations in Syria, to economic policies, to the removal of democratically elected mayors in Kurdish-majority cities). Reflecting on the proliferation of big picture talk, Tanil Bora (2016), a prominent leftist thinker in Turkey, wrote "it is true that one cannot escape [questions] of the big picture. But there is a problem if the big picture prohibits you from looking at anything other than itself, or if it forces you to move your eyes when you are focusing on a 'detail."' 3 He then asks if a poor fellow at the margin of a Pieter Bruegel painting would be simply a small fragment of a big picture, or a sort of big picture in itself, like what a miniature does in building and presenting a world on a small scale. ${ }^{4}$

My question is similar to Bora's: why does the current big picture talk tend to locate the truth of the ongoing pandemic anywhere other than the virus known as 'severe acute respiratory syndrome coronavirus 2' (SARS-CoV-2), which is responsible for the coronavirus disease? Unlike Bora, however, I do not think the big picture, as it is invoked by pro-government pundits, is mainly about the scale of explanation, as there is little concern with the complexity of the social world. From pundits' perspective, those who cannot see the big picture lack the will to consider what is beyond the here and now-not the analytical or conceptual sophistication to make sense of the complexity of global economy or politics.

What is at stake, I suggest, is a particular genre of evidence that approaches the truth at arm's length. That is, big picture talk presumes the telescoping of truth as the big picture truth only reveals itself at a distance. Indeed, in Greek tele-stands for 'far, at a distance' and -scopos for 'one who watches'. Elsewhere, I have written that, from an anthropological perspective, all evidential discourses belong to a given genre, and such discourses become compelling only when they are able to articulate a set of attitudes, sensibilities, and practices (Telliel 2019a, 2019b). I thus invoke the notion of telescoping truth here. For although the big picture is about signaling the involvement of non-proximate actors (i.e., globalists) in national public issues, its rhetorical power lies in its urging of fellow Turks to move further away from where their attention has been directed. How else can one see the big picture?

Telescoping truth is thus predicated on a contrast between the kind of critique it enables and an immanent critique that analyzes global capitalism through the processes internal to its operation. An immanent critique, for instance, might be able to examine the coronavirus's origins as a political ecological problem that is linked to the expansion of urban areas and the destruction of wildlife as part of uncontrolled capitalist growth. From the perspective of telescoping truth, such a critique of capitalism is not as compelling as the scenarios linked to Bill Gates and his alleged plan of introducing a bio-ID system all around the world. ${ }^{5}$ While I do not want to suggest that capitalists eschew elaborate tactics to increase their power, I am not sure that we really need a conspiracy theory involving Bill Gates to know that capitalism has a dark underbelly. My question is rather different: why is anti-globalist critique of global hierarchies anything but immanent? It is as though the truths emerging from an immanent critique are seen through an inverted telescope and thus appear small and insignificant.

In Turkey, thanks to its state-centric perspective, anti-globalism traverses political boundaries between the religious and the secular. Until very recently, secular nationalists had for a long time 
led Turkey's anti-globalist discourse and big picture talk. Today, pandemic-related science skepticism is also well-represented among both secular and religious nationalists. In short, while Turkey's anti-globalism is currently refracted through an Islamic lens, there is nothing necessarily religious (or secular) about telescoping truth. This does not mean that specific political visions do not matter. On the contrary, I believe that the portability and elusiveness of the big picture metaphor demand a closer look at how it is translated into specific political projects. In the rest of this article, I will focus on a recently published commentary by Tahsin Görgün, a prominent Turkish Muslim philosopher, and discuss how anti-globalist discourse translates telescoping truth into a politico-theological critique.

Görgün is a prolific writer and a university professor. He was academically trained in hermeneutics, idealism, and Qur'anic sciences in Turkey and Germany, and has written extensively on the necessity and urgency of renewing Islamic civilization. In a recent commentary titled "The Coronavirus and the End of Post-truth," Görgün (2020) argues that the coronavirus is a harbinger of an era wherein the truth will guide humans. He claims that liberal globalists have masked truths about the human condition by circulating discourses that promote, for example, autonomous individualism, the free market, and fluid sexual identities. The coronavirus's challenges to science and politics, in his view, makes it impossible for liberal globalists to continue with business as usual. While he is not interested in speculations concerning the origin of the coronavirus, Görgün claims that it reveals something other than itself: "It not only affects humans' lives but also threatens their very existence. This is a kind of risk or threat that humans are not able to delineate or define. The coronavirus has thus demonstrated that it has been ... a sign for the manifestation of the truth" (ibid.). Here he draws a distinction between the risk or threat of COVID-19 and the crises that are 'fabricated' by liberal globalists to justify their political, economic, or military involvement in non-Western countries. It seems that the non-human nature of the threat (as opposed to the human-made crises that liberal globalists use to govern societies around the world) is what connects the coronavirus to a theological truth. Görgün indeed claims that "this situation can be best grasped within the light of how the staff of Prophet Moses manifested the truth." Just as the staff, according to the Islamic tradition, became something other than itself (a serpent) and challenged the Pharaoh and others who did not recognize the truth of Moses's prophethood and divine revelation, the coronavirus helps 'unconceal' the truth by playing a role that is larger than itself.

For Görgün, another truth that can now escape liberal globalist ideology's concealment is the continuing significance of strong states. He thinks that by demonstrating the essential need for the state's mobilization and administration of public resources in medicine and other fields, the coronavirus is rendering liberal globalists' promotion of non-state actors obsolete. This is a reflection of a common anti-globalist perspective that frames social movements and human rights activism, which are believed to be controlled or manipulated by liberal globalists, as the antithesis of the state. In the Turkish context, it is this perspective that underlies President Erdoğan's authoritarian policies against Kurdish politicians and human rights activists. Furthermore, the eclipse of liberal globalism is seen not only as a blow against secular hubris or a reassertion of the state-based political visions, but also as an end to the era of post-truth that has eroded traditional family commitments, gender identities, and other Islamic constants (sabiteler).

Görgün is, of course, not alone in associating COVID-19 with the coming of a major global transformation. For instance, in reflecting on the pandemic, Slavoj Žižek (2020: 104) recently wrote that "the lines that separate us from barbarism are drawn more and more clearly. One of the signs of civilization today is the growing perception that continuing the various wars that circle the globe [is] totally crazy and meaningless. So too the understanding that intolerance of other races and cultures, or of sexual minorities, pales into insignificance compared with 
the scale of the crisis we face.” Although Görgün would agree with Žižek on the far-reaching potentials of the pandemic, Görgün thinks that it is liberal globalism that is drifting into insignificance and irrelevance, and that the lines are drawn not between civilization and barbarism, as Žižek suggests, but between liberal globalists and those who are faithful to unchanging truths. The latter, Görgün (2020) claims, are currently presented with "authentic possibilities," so that they can stop liberal globalists' use of fabricated crises to dominate the world. He does not specify what those possibilities might be. Perhaps he does not know yet since he ends his commentary with a note on the necessity of "diagnosing and enunciating these possibilities."

Görgün is not interested in infamous conspiracy theories related to $5 \mathrm{G}$ or Bill Gates that have become popular among most anti-globalists in Turkey. While he writes as a philosopher, what he shares with anti-globalists is a belief that the truth revealed by the coronavirus is something other than itself and that the condition of this truth is predicated on its unmasking of liberal globalists' conspiracies against the nation-state. This is what I call the telescoping of truth: it presumes an economy of truth that is accessible only at a distance. It links COVID-19 to global capitalist figures, but shies away from a critique that highlights public health concerns as part of a complex relationship between global and national actors. Most importantly, it imagines the state not just as an actor among many, but as the ultimate end of collective life. Telescoping truth does what Fredric Jameson (1990) calls 'cognitive mapping' - that is, it helps people map their location in relation to the social and political organization of global capitalism. As such, it spatializes power relations within global capitalism at the expense of temporal processes and contingencies. ${ }^{6}$ Indeed, what could be a better metaphor than 'the big picture' to capture this?

In Turkey and elsewhere, there are people who would share Görgün's concerns and commitments as well as many others whose worldviews would not align with his. Yet, many people are concerned about the predicament of the concept of truth these days. In fact, the Oxford English Dictionary (2016) recognized 'post-truth' as the word of the year in 2016 and provided this definition: "relating to or denoting circumstances in which objective facts are less influential in shaping public opinion than appeals to emotion and personal belief." Since then, the post-truth debates have narrowly approached the question of truth as a matter of cognitive bias or logical fallacy (e.g., McIntyre 2018), ignoring the extent to which truth claims may depend on particular visions of collective life. If truth is not only an epistemological question and is about how we want to live our lives together with others (which is more important than ever during this pandemic), we need to move beyond the apologetic positivism of the post-truth debates. This is, I believe, one of the main challenges that anti-globalists pose for us as anthropologists: truth as a political question.

\section{ACKNOWLEDGMENTS}

I am grateful for the feedback I received from Hayal Akarsu, Saygun Gökarıksel, Hakan Karpuzcu, and Enis Köstepen while preparing this article. Special thanks to Shana Lessing for the many insightful conversations that helped me develop my thinking on this piece. 
YUNUS DOĞAN TELLIEL is an Assistant Professor of Anthropology and Rhetoric at Worcester Polytechnic Institute (WPI). His research interests include the anthropology and philosophy of language; religion, science, and secularism; and technology ethics. He is currently working on a book manuscript, "What Is the Language of Islam?", focusing on Qur'an translations and debates around language in modern Turkey. He is also the Co-director of the Applied Robot Ethics Lab at WPI. His new research focuses on the relationship between design and moral imagination in robotics. E-mail: ydtelliel@wpi.edu

\section{NOTES}

1. This is not unique to Turkey. According to a recent Pew Research Center poll, 25 percent of the surveyed Americans believe there is some truth to the claim that COVID-19 was planned (Schaeffer 2020).

2. See, for instance, Stratfor's promotional video on Twitter, https://twitter.com/Stratfor/status/757743519268241409, or this analysis on the Stratfor website https://worldview.stratfor.com/ article/global-trade-looking-big-picture.

3. All translations from Turkish are my own.

4. Bruegel's paintings can be seen at the National Gallery of Art, https://www.nga.gov/collection/artistinfo.1031.html\#works.

5. For a discussion of some of these recent Bill Gates-related conspiracy theories, see Wakefield (2020).

6. While it seems that cognitive mapping is central to all ideologies, conspiracy theory, Jameson (1990: 356) claims, is "the poor person's cognitive mapping in the postmodern age; it is a degraded figure of the total logic of late capital, a desperate attempt to represent the latter's system." I am not sure Jameson is correct about the specific class character of conspiracy theories. In places like Turkey and the US, conspiracy theories related to COVID-19 have traveled well across different classes. In addition, I am not convinced that there is always a clear distinction between conspiracy theories and other ideological explanations. Take anti-black racism in the US, for instance. Although it is built on fantasies and paranoias similar to many conspiracy theories, it is rarely discussed as a form of conspiratorial thinking. Indeed, it seems that the conspiratorial cognitive mapping done by white-collar workers and their employers has a different name: bias.

\section{REFERENCES}

Altun, Murat, and Sinan Erensü. 2014. "Madur-Muktedirden Paralel Cadıya: Komplo Teorilerini ve Güncel Siyaseti Antropolojinin Koridorlarında Aramak" [From the powerful victim to the parallel witch: Looking at conspiracy theories and current politics from anthropology]. Teorik Bakış 5: 75-90.

Anadolu Agency. 2013. “Turkish PM Urges Protesters to 'See Big Picture.” Anadolu Agency, 11 June. https://www.aa.com.tr/en/archive/turkish-pm-urges-protesters-to-see-big-picture/239194.

Bloch, Maurice. 2008. "Truth and Sight: Generalizing without Universalizing." Journal of the Royal Anthropological Institute 14 (S1): S22-S32.

Bora, Tanıl. 2016. "Büyük resmi görmek” [Seeing the big picture]. Birikim Dergisi, 30 March. https:// www.birikimdergisi.com/haftalik/7598/buyuk-resmi-gormek.

Görgün, Tahsin. 2020. "Koronavirüs ve Post-Truth'un Sonu" [The coronavirus and the end of posttruth]. İLEM Blog, 11 May. http://blog.ilem.org.tr/tahsin-gorgun-koronavirus-ve-post-truthun-sonu/.

Jameson, Fredric. 1990. "Cognitive Mapping." In Marxism and the Interpretation of Culture, ed. Cary Nelson and Lawrence Grossberg, 347-360. Champaign: University of Illinois Press.

McIntyre, Lee. 2018. Post-Truth. Cambridge, MA: MIT Press. 
Nefes, Türkay Salim. 2017. “The Impacts of the Turkish Government's Conspiratorial Framing of the Gezi Park Protests." Social Movement Studies 16 (5): 610-622.

Oxford English Dictionary. 2016. "Word of the Year 2016." Oxford University Press. https://languages. oup.com/word-of-the-year/2016/.

Schaeffer, Katherine. 2020. "A Look at the Americans Who Believe There is Some Truth to the Conspiracy Theory That COVID-19 Was Planned." Pew Research Center, 24 July. https://www.pewresearch. org/fact-tank/2020/07/24/a-look-at-the-americans-who-believe-there-is-some-truth-to-the-conspiracy-theory-that-covid-19-was-planned/.

Telliel, Yunus Doğan. 2019a. "Introduction: Studying Evidence and Religion in Post-Truth Times." Comparative Studies of South Asia, Africa and the Middle East 39 (3): 495-499.

Telliel, Yunus Doğan. 2019b. "Miraculous Evidence: Scientific Wonders and Religious Reasons." Comparative Studies of South Asia, Africa and the Middle East 39 (3): 528-542.

Wakefield, Jan. 2020. "How Bill Gates Became the Voodoo Doll of Covid Conspiracies." BBC News, 5 June. https://www.bbc.com/news/technology-52833706.

Žižek, Slavoj. 2020. Pandemic! COVID-19 Shakes the World. New York: OR Books 


\title{
$\longrightarrow$ \\ Learning from Religious Diasporas in Pandemic Times
}

\author{
Heather Mellquist Lehto
}

The word 'diaspora', notes Stéphane Dufoix (2008), was first used in the Septuagint to denote a separation that is imposed by God. Humans alone cannot mend such separation; they can only demonstrate piety in the hope that their actions might move God to intervene once again. Diaspora, in other words, is a state of dissolution, catalyzed by a force beyond humans and to which humans must respond with careful, deliberate appeals.

Scholars of religion may not be a diaspora during the COVID-19 pandemic, yet we share a heightened awareness of our estrangement. Because rituals help constitute places, prolonged social distancing has been disorienting for many of us. Scholars in North America have been working almost exclusively from home for several months. We miss being with our friends, our family, our students, and our colleagues. We miss the classroom and its particular form of collective effervescence. We miss the relative tranquility of our offices, as well as all of the research materials we had to leave on campus in the spring. The fields that many of us imagined for our research projects have vanished. Zoom-ing into meetings and social gatherings has not delivered the transcendent dream of science-fictive teleportation. We are always at home and constantly homesick, calling forth Julie Chu's (2010) insight that immobility may be experienced as its own form of displacement (see also Jackson 2013). But these are practices that we believe to be the pious acts befitting our pandemic condition: avoiding spaces that may be rife with impurities, wearing masks and gloves, and choreographing our public movements around invisible clouds of airborne particles.

While the pandemic has brought unique challenges, it is perhaps worth remembering that so much of our lives prior to it had already been colored by the experience of dislocation. Before today's public health directives, geopolitical and economic conditions regularly led many people to shelter in a different place than they might wish, as many scholars know first-hand. The choice of where academics can live and work is almost always constrained. Field research usually draws us away from home, and our returns separate us from the people with whom we live in the field. Our sense of the world we inhabit shifts, dilates, and contracts with each move. For me personally, two years of field research and three postdoctoral fellowships have brought me to live in six cities in seven years. My husband and I are more practiced at socially distant marriage over the phone than we are at cohabitation. Our lives during this pandemic, then, are at once familiar and strange, an interstitial position that has proven fruitful for social scientific reflection.

As we make adjustments to the pandemic and prepare for its lasting consequences, the hardfought wisdom of religious diasporas may be especially pertinent, as diasporas show "displaced groups ... engaging their creative forces in the use of things, bodies, words, and acts to deal with a perceived spatial crisis, to close or dwell in a gap between the 'here' and 'there' in ways that are socially consequential" (Johnson 2012: 103). Diasporas may be relational networks characterized by dislocation, but the recognition of one's own dislocation entails that the world is 
not ordered as one may like it to be. Diasporas belie their own separation in the here and now in order to posit an otherwise. In other words, diasporas are at once characterized by forms of estrangement and also by coordinated, creative activity to build alternative social forms, often through imaginative geography and history, that enable people to create "new kinds of subjects" and "to discover places from which to speak" (Hall 1998: 237).

Considerable research into religious diasporas offers us insights into how dispersed individuals call new social collectives into being, which both we and our students might benefit from revisiting (see Barber 2011; Boyarin and Boyarin 1993; Daswani 2015; Garnett and Hausner 2015; Gilroy 1994; Johnson 2007; Levitt 2001; Quayson and Daswani 2013; Tweed 2006). In this piece, I want to offer one particular model for religious diaspora drawn from ethnographic research in Korean Christian diasporas. Many Korean Christians have found it helpful to frame efforts to repair geographic separation as an infrastructural project-in their words, building 'holy infrastructure' that provides the material-spiritual conditions for the translocal communication of grace and the Holy Spirit, and ultimately for creating a more Christian world.

\section{Religious Diaspora as Holy Infrastructure}

A multi-site church is a single church that meets at multiple locations, often by recording services at one location and broadcasting them to 'satellite' church campuses. Broadcasting services to dispersed congregations is new for many Christians during this pandemic, but the Korean churches I have studied have congregated across numerous campuses throughout the world since the 1980s, as increasing numbers of emigrants forged Korean diasporic communities abroad. In the United States, Christian churches have been vital to South Korean emigration, helping immigrants adjust to life as an ethnic minority while maintaining relationships with those who have continued to live in South Korea.

I learned from these diasporic Christian communities that one might conceive of collective practices over space as an infrastructural project-or, as one church described it, as building 'holy infrastructure' (kŏrukhan inp'üra). With this perspective, every person, every object, and every action can be reframed as a potential conduit-or a potential barrier-for the movement of the Holy Spirit or God's blessings. Beyond beliefs alone, Christian life in these transnational churches is principally about, in the words of Walter Benjamin (1968: 108), the "co-ordination of the soul, the eye, and the hand." The concept of 'holy infrastructure' is especially useful for conceptualizing diasporic Christian practice here, because both the infrastructure and that which the infrastructures carry may be variously material and immaterial. This allows practitioners to make invisible movements present, with which one may then act in hopeful coordination.

Korean multi-site churches are constituted through the use of audio-visual and print media, as is often the case with transnational religious communities (see, e.g., Beliso-de Jesús 2013). Over the last several decades, these churches have eagerly experimented with cutting-edge media and bureaucratic technologies, searching for the most effective means to both spread the Gospel and provide congregants with a sense of Christian community, no matter their location. Many Christians who live abroad and watch pre-recorded services at 'satellite' campuses understand their participation to be more than a virtual imitation of the in-person services. Ritual engagements with the television screens are a condition for the emergence of a particular configuration of Christian community. The screens become transformed theologically into prosthetics of the pastor, allowing him or her to perform the Pentecostal healing ritual of 'laying on of hands' despite the fact that the healed congregant's body is often an ocean away from the pastor's hands (see Mellquist Lehto 2017). Building and website architectures are also understood to work as holy infrastructure, 
facilitating the circulation of human bodies, information, and the Holy Spirit. As people's bodies, actions, and the objects of their practice become seen for their infrastructural dimension, emphasis is placed on what else they might capacitate, both in the present and in the future.

Since 2014, I have spent time with 'IT missionaries' to learn how people understand the technologies that are central to their dispersed congregations. As the prefix 'infra-' denotes, infrastructures are integrated systems that stand 'within' or 'beneath', and their operation is often obscured. As a consequence, exactly how one builds and maintains infrastructures for a better-or more holy-world is often uncertain. Christians regularly doubt the efficacy of their efforts and must resist the temptation to resign themselves to live isolated from other members of their Christian communities.

The students at the IT mission school were not IT professionals or professional missionaries. Many of them were teachers, housewives, or office workers who had little or no computer science training. One woman referred to herself as a 'computer illiterate' person (kómmaeng), but despite this lack of confidence in her own effectiveness, she continued to work as an IT missionary. When in doubt, they drew on-and cultivated - faith.

A woman named Sae-mi used her Instagram and Pinterest accounts to transform social media into a mission field. Sae-mi lived with her husband on the periphery of Seoul. She had worked as a teacher in her early twenties, but the familial responsibilities she felt as a new wife and daughterin-law led her to quit her job. With her husband at work for most of the day and night, she spent more time than she might wish on social media as a way of passing time. The idea of becoming an IT missionary, then, seemed appealing to her because of its promise for social and spiritual connection despite geographic isolation in her apartment. She prayed everyday over Instagram, asking God to lead her to direct certain messages to strangers-particularly ethnic Koreans and other Korean speakers abroad-who might respond to this kind of ministry. She did not understand the algorithms within these platforms, and so often she doubted that her messages would be read at all, let alone by a receptive audience. Sometimes these limitations created ambivalence:

As they say, the Spirit can move through technology, and I really do feel touched sometimes. But it might be silly-I don't know. Sometimes when I am sitting alone at home, just posting things and commenting on strangers' posts, I think, 'I'm a real fool [pabo], huh?' [laughter] I mean, it's weird, right? You can spend hours on Instagram, and then suddenly realize all that time is gone. And what have I done?

Nevertheless, she prayed that God might direct her actions in Seoul, the social media algorithms, and the activities of geographically distant strangers. "At those times, I don't know whether or not I am doing anything at all. I must have faith/believe [mitta] that God is doing things for us that I don't know about. But if I pray and follow Him, I have faith that the Lord will lead."

Faith was a necessary resource upon which Sae-mi drew, and it was also a virtue cultivated through this practice. When Sae-mi refers to 'faith' in God, we should not understand this as a Kierkegaardian belief in the incomprehensible, but as the capacity to place limits on one's own agency in deference to a higher power-what Hirokazu Miyazaki (2000: 43) describes in reference to Fijian Christians as an "abeyance of agency." By working toward her goal to grow the transnational church-despite her recognition that she had no control over the 'real world' effects of her digital actions-Sae-mi realized her faith by submitting her efforts to the mysterious operation of the Holy Spirit, which she believes operates within and exceeds the social media platforms.

What is notable about this and many religious diasporas is a consistent refusal to give in to the easy consolations of an unpleasant present. Believers build infrastructures for the world they want, not just the world that they can endure. Within these particular transnational churches, Christians engage in world building focused on facilitating an ideal form of life through a 
coordination of the material and the immaterial, the human and the non-human, the natural and the technological. Under this framework, each prayer, sermon video, social media alert, bowl of kimchi soup, click of a mouse-all participate in bringing a more holy world into being. At once mundane and sublime, each action is approached as infrastructural, bridging immediate, everyday practices and ultimate ambitions.

\section{Infrastructuring in the Meantime}

The Korean Christian diaspora uses the tools at hand not just to make do in the present, but also to capacitate a more livable future, building a bridge to nowhere-yet. A church's technological systems, buildings, administration, and attendant human networks-as holy infrastructuresare powerfully directive of social and political life. This is what might be called an infrastructural imaginary', a concept that has become increasingly adopted within the social sciences and humanities as well (see Anand et. al. 2018; Berlant 2016; Handman 2017; Knox 2017; Larkin 2013; Peters 2015; Simone 2004; Star 1999; Warner 2018). These infrastructural imaginaries gesture toward a shared sense of human life being increasingly defined by the often unseen networks of contact and communion, conscription, and contagion.

Thinking infrastructurally may also help us to envision better lives beyond the pandemic and to use this time-as we are variously able-to create infrastructures that might support that goal. This provides a way for us to think about our lived experience within the pandemic not as a rupture, but as a junction in which time, opportunities, resources, and suffering might be redistributed according to the systems we build in the meantime (Caduff 2020). As Kamari Clarke recently urged, anthropology might seize this moment to engage in "a process of disaggregation and reformulation that allows for the reconfiguration of particular social orders and the establishment of new baselines for alternate possibilities" (in Jobson et al. 2020).

I hesitate to offer prescriptions about which scholarly infrastructures we ought to tend to and how. This is an unending collective project. Yet I am particularly heartened by the wave of scholars offering their talents to address the concerns of this moment across social media, in public lectures via Zoom, in special journal features, through collaborations with social justice and public health organizations, and in the news media. It is understandable that scholars and educators often feel dismissed and ill supported. It is easy to be disheartened while in-person instruction is being debated with little input from instructors and, in some cases, the health of educators is subordinated to the financial health of our schools or the economy writ large. At the same time, the considerable non-academic audience that has engaged with these pandemicrelated Zoom lectures, online articles, and news interviews attests to the fact that there is a public eager to hear our voices that is larger than we often think. The vitality of our academic institutions-especially public institutions-depends upon the trust and respect of the surrounding communities, and these activities help to demonstrate why our work matters, both within and beyond the classroom. The economic stress that the pandemic places on universities has meant that many academic careers have been interrupted, if not cut short altogether. When senior colleagues expand public appreciation of our fields, they cast lifelines to early career scholars like myself, who hope to find sustainable careers in higher education.

A common critique of multi-site churches that rely on audiovisual broadcasting is that the use of this medium leads to a consumeristic understanding of religious participation. The same concern has been raised about Zoom teaching. However, my research demonstrates that multisite church pastors work to couple this diasporic church form with other Christian practices that, in fact, enable congregants to assume roles that might not be available to them in large, 
single-location churches. In a similar vein, as we begin an academic year of Zoom meetings and social distancing, we might reflect on the research that speaks to the co-construction of media and publics (Hirschkind et al. 2017; Warner 2002). In Zoom after Zoom, what practices will be infrastructural to sustain modes of attention and inattention appropriate to our academic traditions (see Hirschkind 2006)? What might we need to change in order to still see, listen, and think as the scholars, colleagues, and educators we want to be?

The recent Distribute2020 conference (convened by the Society for Cultural Anthropology and the Society for Visual Anthropology) provided one notable model for virtual scholarly practice, although not due to its virtuality alone, which few would say was ideal. Rather, it was because the digital infrastructures were used to capacitate other goods. The conference's displacement fostered a more lateral conference, dramatically reduced economic barriers to attendance, decreased its carbon footprint, and fostered greater collaboration with artists and activists around the world. The Immanent Frame's "Practices of relation" forum provides another model, whereby the ubiquity of online academic discussion provides incentive to begin overdue conversations across disciplines and regions. These two examples might be seen as forging new infrastructural arrangements, doing what one can in the moment to create a different community for when the pandemic has lifted.

Our social and professional activities during this extended pandemic may be shot through with compromise and consolation (whenever is this not the case?). As Anand Pandian (2020) offered recently: "[Our work] may happen, for some time, through virtual portals and networks and devices and relays of various kinds. But say we began to do this work anyway. When the driving pressure of this moment begins to ebb, as it will, where might we find ourselves? What kind of anthropology will we have made possible?" When a vaccine emerges as our own deus ex machina to lift our pandemic displacements, who will we have become?

HEATHER MELLQUIST LEHTO is a cultural anthropologist focusing on religion, technology, and social relations in South Korea and the United States. Her book manuscript, "Holy Infrastructure: The Multisite Church Revolution in South Korea and the United States," explores the coordination of technological and religious innovation in transnational Korean churches. Currently a Postdoctoral Research Fellow at Arizona State University, her work has been published in the Journal of Korean Studies, Somatosphere, and Acta Koreana, and on PRI's radio program The World. E-mail: heather.mellquist@gmail.com

\section{REFERENCES}

Anand, Nikhil, Akhil Gupta, and Hannah Appel, eds. 2018. The Promise of Infrastructure. Durham, NC: Duke University Press.

Barber, Daniel Colucciello. 2011. On Diaspora: Christianity, Religion, and Secularity. Eugene, OR: Cascade Books.

Beliso-de Jesús, Aisha. 2013. "Religious Cosmopolitanisms: Media, Transnational Santería, and Travel between the United States and Cuba." American Ethnologist 40 (4): 704-720.

Benjamin, Walter. 1968. “The Storyteller: Reflections on the Works of Nikolai Leskov." In Illuminations, trans. Harry Zohn, 83-109. New York: Schocken Books.

Berlant, Lauren. 2016. “The Commons: Infrastructures for Troubling Times." Environment and Planning D: Society and Space 34 (3): 393-419. 
Boyarin, Daniel, and Jonathan Boyarin. 1993. "Diaspora: Generation and the Ground of Jewish Identity." Critical Inquiry 19 (4): 693-725.

Caduff, Carlo. 2020. "What Went Wrong: Corona and the World after the Full Stop." Medical Anthropology Quarterly. 21 July. https://doi.org/10.1111/maq.12599.

Chu, Julie Y. 2010. Cosmologies of Credit: Transnational Mobility and the Politics of Destination in China. Durham, NC: Duke University Press.

Daswani, Girish. 2015. Looking Back, Moving Forward: Transformation and Ethical Practice in the Ghanaian Church of Pentecost. Toronto: University of Toronto Press.

Dufoix, Stéphane. 2008. Diasporas. Trans. William Rodarmor. Berkeley: University of California Press.

Garnett, Jane, and Sondra L. Hausner, eds. 2015. Religion in Diaspora: Cultures of Citizenship. Basingstoke: Palgrave Macmillan.

Gilroy, Paul. 1994. “Diaspora." Paragraph 17 (3): 207-212.

Hall, Stuart. 1998. "Cultural Identity and Diaspora." Identity: Community, Culture, and Difference, 2nd ed., ed. Jonathan Rutherford, 222-237. London: Lawrence \& Wishart.

Handman, Courtney. 2017. "Walking Like a Christian: Roads, Translation, and Gendered Bodies as Religious Infrastructure in Papua New Guinea." American Ethnologist 44 (2): 315-327.

Hirschkind, Charles. 2006. The Ethical Soundscape: Cassette Sermons and Islamic Counterpublics. New York: Columbia University Press.

Hirschkind, Charles, Maria José de Abreu, and Carlo Caduff. 2017. "New Media, New Publics? An Introduction to Supplement 15." Current Anthropology 58 (S15): S3-S12.

Jackson, Michael. 2013. The Wherewithal of Life: Ethics, Migration, and the Question of Well-Being. Berkeley: University of California Press.

Jobson, Ryan Cecil, Kamari Clarke, and Lucia Cantero. 2020. "The Case for Letting Anthropology Burn? Considerations and Reflections." American Anthropologist website, 20 July. http://www.americananthropologist.org/2020/07/20/the-case-for-letting-anthropology-burn/.

Johnson, Paul Christopher. 2007. Diaspora Conversions: Black Carib Religion and the Recovery of Africa. Berkeley: University of California Press.

Johnson, Paul Christopher. 2012. "Religion and Diaspora." Religion and Society: Advances in Research 3: 95-114.

Knox, Hannah. 2017. “Affective Infrastructures and the Political Imagination." Public Culture 29 (2 (82): 363-384.

Larkin, Brian. 2013. “The Politics and Poetics of Infrastructure." Annual Review of Anthropology 42: 327-343.

Levitt, Peggy. 2001. The Transnational Villagers. Berkeley: University of California Press.

Mellquist Lehto, Heather. 2017. "Screen Christianity: Video Sermons in the Creation of Transnational Korean Churches.” Acta Koreana 20 (2): 395-421.

Miyazaki, Hirokazu. 2000. "Faith and Its Fulfillment: Agency, Exchange, and the Fijian Aesthetics of Completion." American Ethnologist 27 (1): 31-51.

Pandian, Anand. 2020. "Anthropology in Times of Radical Unease." Fieldsights, 4 June. https://culanth. org/fieldsights/anthropology-in-times-of-radical-unease.

Peters, John Durham. 2015. The Marvelous Clouds: Toward a Philosophy of Elemental Media. Chicago: University of Chicago Press.

Quayson, Ato, and Girish Daswani, eds. 2013. A Companion to Diaspora and Transnationalism. Malden, MA: Blackwell.

Simone, A. M. (Abdou Maliqalim). 2004. "People as Infrastructure: Intersecting Fragments in Johannesburg." Public Culture 16 (3): 407-429.

Star, Susan Leigh. 1999. “The Ethnography of Infrastructure." American Behavioral Scientist 43 (3): 377-391.

Tweed, Thomas A. 2006. Crossing and Dwelling: A Theory of Religion. Cambridge, MA: Harvard University Press.

Warner, Michael. 2002. "Publics and Counterpublics." Public Culture 14 (1): 49-90.

Warner, Michael. 2018. "Infrastructure as Ethics." UC Berkeley Tanner Lectures. https://tannerlectures. berkeley.edu/2017-2018-lecture-series/. 